\title{
Taraxerol exerts potent anticancer effects via induction of apoptosis and inhibition of Nf-kB signalling pathway in human middle ear epithelial cholesteatoma cells
}

\author{
Jun Liao*, Fengfang Wu, Wen Lin, Zhiwei Huang \\ Department of Otolaryngology, Quanzhou First Hospital Affiliated to Fujian Medical University, Quanzhou, Fujian 362000, \\ China \\ *For correspondence: Email: janetsntal@yahoo.com; Tel/Fax: +86 59522277031
}

Sent for review: 25 October $2017 \quad$ Revised accepted: 18 May 2018

\begin{abstract}
Purpose: To investigate the effect of taraxerol on the proliferation of middle ear epithelial cholesteatoma cells.

Methods: The anti-proliferative effect of taraxerol was investigated by cell counting kit-8 (CCK8) and clonogenic assays. Apoptosis was measured using DAPI, while mitochondrial membrane potential was determined with the aid of rhodamine 123 staining. Protein expression was studied by western blotting.

Results: Taraxerol induced concentration-dependent anti-proliferative effects on the middle ear epithelial cholesteatoma cells, and also inhibited their colony formation potential. The drug induced apoptosis in the middle ear epithelial cholesteatoma cells by reducing mitochondrial membrane potential, and also triggered sub-G1 cell cycle arrest in these cells. Moreover, taraxerol inhibited the expression of $\mathrm{Nf}-\mathrm{kB}$.

Conclusion: These findings reveal that taraxerol may be a potential lead compound for the treatment of middle ear cholesteatoma.
\end{abstract}

Keywords: Cholesteatoma, Epithelial tissues, Taraxerol, Apoptosis, Cell cycle arrest

\begin{abstract}
This is an Open Access article that uses a funding model which does not charge readers or their institutions for access and distributed under the terms of the Creative Commons Attribution License (http://creativecommons.org/licenses/by/4.0) and the Budapest Open Access Initiative (http://www.budapestopenaccessinitiative.org/read), which permit unrestricted use, distribution, and reproduction in any medium, provided the original work is properly credited.

Tropical Journal of Pharmaceutical Research is indexed by Science Citation Index (SciSearch), Scopus, International Pharmaceutical Abstract, Chemical Abstracts, Embase, Index Copernicus, EBSCO, African Index Medicus, JournalSeek, Journal Citation Reports/Science Edition, Directory of Open Access Journals (DOAJ), African Journal Online, Bioline International, Open-J-Gate and Pharmacy Abstracts
\end{abstract}

\section{INTRODUCTION}

Middle ear cholesteatoma is a very serious pathology which results from proliferation of epithelial tissues. The reasons for the extension into the middle ear and aetiology of cholesteatotoma are yet to be fully understood [1]. However, it is believed that the epithelium proliferates due to some growth stimulus, leading to chronic inflammation [2]. A few studies reported the involvement of infections in the onset of cholesteatoma. However, many other studies have suggested the involvement of inflammatory cytokines [3]. Cholesteatoma causes serious bone destruction during its proliferation, and the current treatment strategies are not only insufficiently effective, but are also associated with several side effects [4].

Natural products are considered important sources of compounds that can be utilized for the management cholesteatoma. A number of 
currently used drugs are derived from natural sources and new drugs from natural sources are being frequently discovered [5]. Moreover, compounds derived from natural sources are thought to be comparatively less toxic than their synthetic counterparts [6]. Plants are important sources of drugs. Indeed, a number of drugs currently used in clinics have their origins in plants [5].

Clitoriaternatea L. (butterfly pea) is an important medicinal plant and a source of some important bioactive compounds. It has been utilised in the management of numerous diseases and disorders such as chronic bronchitis, goitre, leprosy, mucous and dropsy $[7,8]$. The roots of this plant are important sources of two important compounds taraxerol and taraxerone. Taraxerol is a pharmacologically important compound that has been reported to exhibit tremendous pharmacological activities which include antitumour, antimicrobial and anti-inflammatory properties [9].

This investigation was performed to find out the impact of taraxerol on cultured human middle ear epithelial cholesteatoma cells.

\section{EXPERIMENTAL}

\section{Cell cultures, chemicals and regents}

Cultured human middle ear epithelial cholesteatoma cells were obtained from Type Culture Collection of Chinese Academy of Sciences, Shanghai, China. The study was approved the Ethical Committee of Quanzhou First Hospital Affiliated to Fujian Medi cal University (approval number: QFH/0987C/2016). All the procedures used were as per standard guidelines [10]. Taraxerol (98\% HPLC-pure) and all other chemicals were obtained from Sigma-Aldrich Ltd, US.

\section{Anti-proliferative and colony formation assays}

The impact of taraxerol on the proliferation of human middle ear epithelial cholesteatoma cells was investigated by CCK8 assay. The cells $\left(5 \times 10^{3}\right)$ were grown in a ninety-six well plate and subjected to incubation at $37{ }^{\circ} \mathrm{C}$ in an atmosphere of $5 \% \mathrm{CO}_{2}$. Following this, the cells were administrated with various doses of taraxerol $(0,7.5,15$, and $30 \mu \mathrm{M})$ for overnight. Thereafter, the addition of CCK8 $(10 \mu \mathrm{L})$ was done and incubated at $37^{\circ} \mathrm{C}$ for $50 \mathrm{~min}$. The optical density of each well's content was read at $450 \mathrm{~nm}$ using a microplate spectrophotometer.
Cell proliferation calculated as percentage of the control.

\section{Colony formation assay}

Cultured human middle ear epithelial cholesteatoma cells were seeded at 200 cells/well. Thereafter, the cells were incubated for $48 \mathrm{~h}$ to allow for attachment, after which they were exposed to different doses $(0,7.5,15$ and $30 \mu \mathrm{M})$ of taraxerol. The cells were then subjected to incubation for 6 days, and thereafter washed with PBS, and treated with methanol for colony fixation. The crystal violet staining of the colonies was performed for about $30 \mathrm{~min}$, and counted under the light microscope as described previously [10].

\section{Apoptosis assay}

The cholesteatoma epithelial cells were grown at $2 \times 10^{5}$ cell density per well in ninety six-well plates and subjected to treatment with varied doses of taraxerol $(0,7.5,15$, and $30 \mu \mathrm{M})$, followed by incubation for $24 \mathrm{~h}$. They were then stained with DAPI, and there after subjected to PBS washing and then fixed in formaldehyde (10\%). The DAPI-stained cells were then observed and photography under a fluorescent microscope as described previously [11].

\section{Determination of mitochondrial membrane potential}

Mitochondrial membrane potential of the middle ear epithelial cholesteatoma cells was studied using confocal microscopy, following staining with rhodamine123 (Rh123). Taraxerol-treated and cultured cells at a density of $2 \times 10^{5} / \mathrm{mL} /$ well were grown in six-well plates and incubated for $24 \mathrm{~h}$. This was followed by trypsinization and washing with PBS and then re-suspended in the medium and stained with rhodamine 123, followed by incubation for $25 \mathrm{~min}$ at $37{ }^{\circ} \mathrm{C}$. Thereafter the cells were collected and washed with PBS, and then finally examined using a laser scanning confocal microscope as described previously [12].

\section{Cell cycle analysis}

To investigate the distribution of middle ear epithelial cholesteatoma cells in various cell cycle phases, the taraxerol-treated $(0,7.5,15$, and $30 \mu \mathrm{M})$ cells were collected and twice subjected to PBS washing. This was followed by fixation of the cells in ethanol $(70 \%)$ for $1 \mathrm{~h}$. The cells were finally re-suspended in propidium iodide solution (50 $\mu \mathrm{l} / \mathrm{mL})$ and RNase1 $(250 \mu \mathrm{g} / \mathrm{mL})$ and then subjected to incubation for 
30 min at $25^{\circ} \mathrm{C}$. Finally, the dissemination of the cells in various phases of cell cycle was estimated using fluorescence-activated cell sorting cater-plus cytometer at 10,000 cells/group as described previously [13].

\section{Western blotting}

Taraxerol-treated ear epithelial cholesteatoma cells were lysed in lysis buffer, and proteins were harvested. The concentration of proteins in each sample was determined by BCA assay, and Western blotting was carried out as described previously [1].

\section{Statistical analysis}

Data were shown as mean (of three biological replicates) \pm SD. Statistical analysis was performed using student's t test by GraphPad prism 7software. Values of $p<0.01$ were taken as indicative of statistically significant differences.

\section{RESULTS}

Taraxerol exerted anti-proliferative effects on epithelial cholesteatoma cells

The results obtained showed that taraxerol inhibited the proliferation of middle ear epithelial cholesteatoma cells in a concentrationdependent fashion (Figures $1 \mathrm{~B}-\mathrm{C}$ ).

Taraxerol inhibited colony formation of epithelial cholesteatoma cells

The colony formation potential of cultured middle ear epithelial cholesteatoma cells were significantly and dose-dependently inhibited by taraxerol $(p<0.01$, Figure $2 \mathrm{~A}$ and $\mathrm{B})$.
Taraxerol induced apoptosis in epithelial cholesteatoma cells

Taraxerol induced apoptosis in epithelial cholesteatoma cells as obvious from the development of apoptotic crops and cell blebbing (Figure 3A). Moreover, the apoptosis-inducing potential of taraxerol was concentrationdependent, and the apoptotic cell percentage cells significantly $(p<0.01)$ enhanced with increase in taraxerol concentration (Figure $3 \mathrm{~B}$ ).

\section{Taraxerol reduced mitochondrial membrane potential of epithelial cholesteatoma cells}

Taraxerol reduced mitochondrial membrane potential in a concentration-dependent manner (Figure 4 A - B).

Taraxerol triggered cell cycle arrest in epithelial cholesteatoma cells

It was observed that taraxerol caused significant enhancement in the sub-G1 cell populations of the cells, ultimately leading to sub-G1 cell cycle arrest. These effects of taraxerol were also concentration-dependent (Figure 5).

\section{Taraxerol suppressed Nf-kB expression in epithelial cholesteatoma cells}

The effect of taraxerol on the expression of Nf-kB was investigated by western blotting. The results showed that taraxerol down-regulated the expression of Nf-kB in middle ear cholesteatoma epithelial cells in a concentration-dependent manner (Figure 6).
A



B

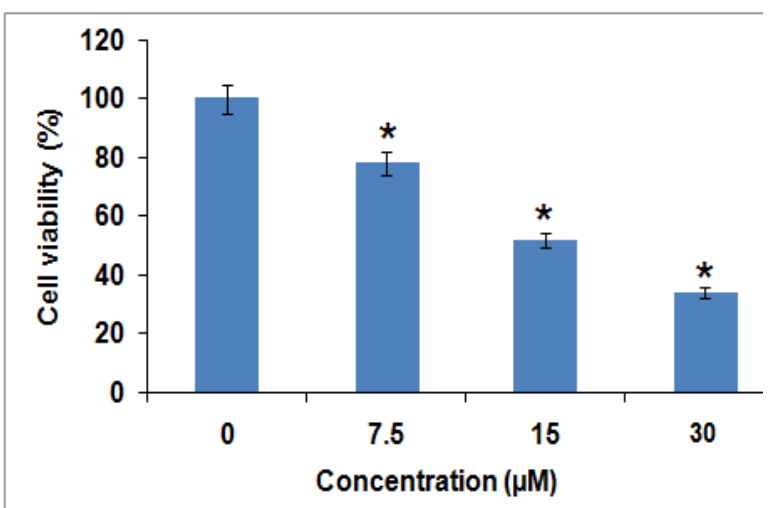

Figure 1: (A) Chemical structure of taraxerol. (B) Effect of taraxerol on the proliferation of human middle ear epithelial cholesteatoma cells at the indicated doses. $(n=3),{ }^{*} p<0.01$. 


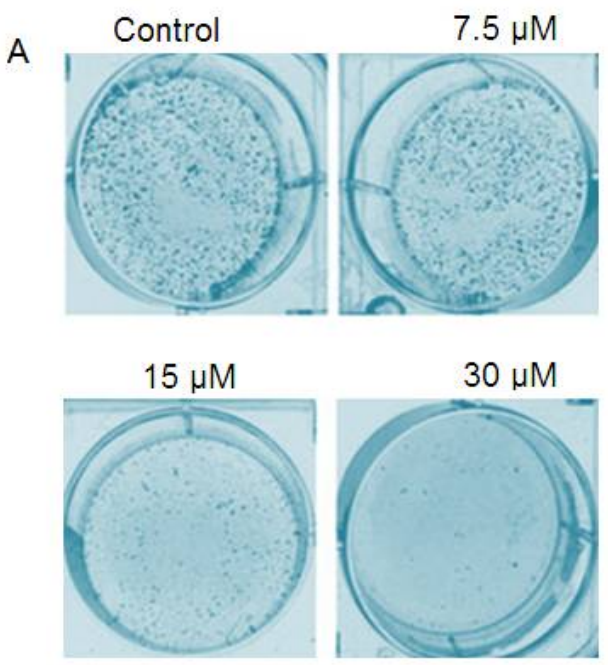

B

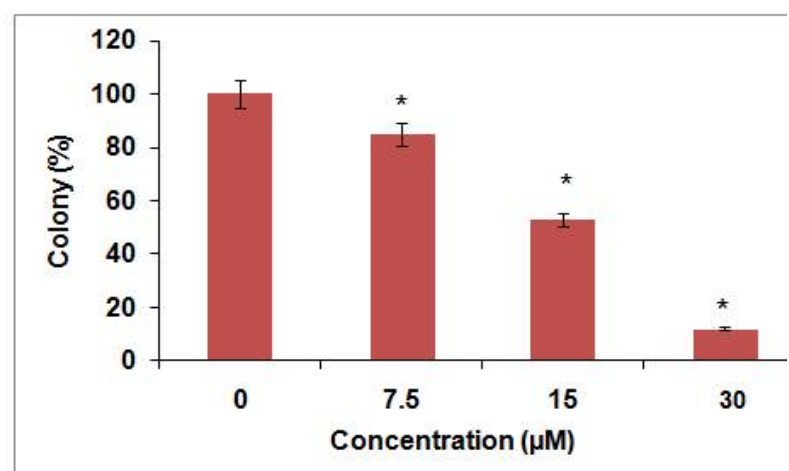

Figure 2: Effect of taraxerol on the colony formation potential. (A) Plates showing effect of taraxerol on colony formation in human middle ear epithelial cholesteatoma cells. (B) Quantification of the colonies $(n=3),{ }^{*} p<0.01$.

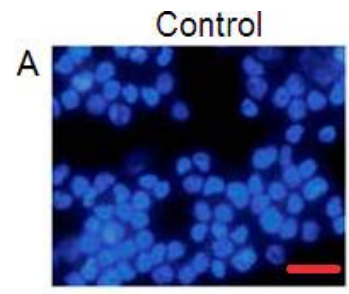

$15 \mu \mathrm{M}$

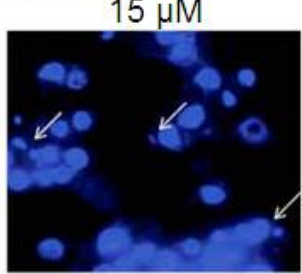

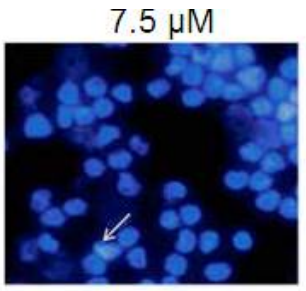

$30 \mu \mathrm{M}$

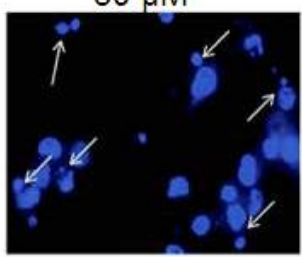

B

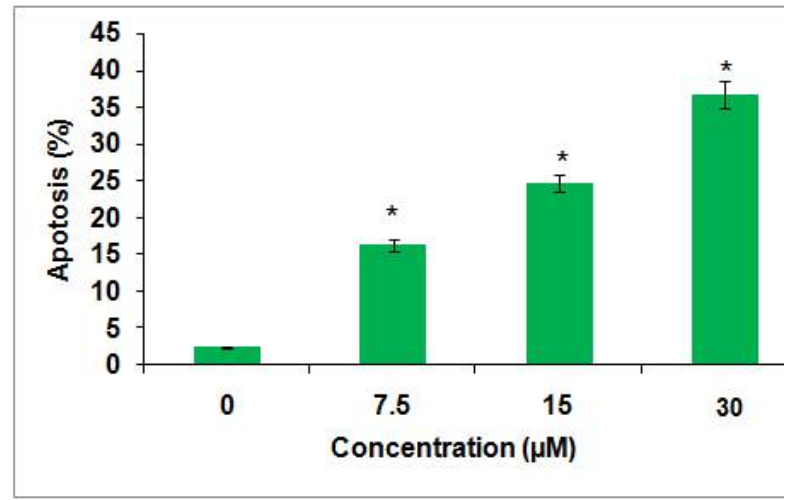

Figure 3: Taraxerol-induced apoptosis in human middle ear epithelial cholesteatoma cells. (A) DAPI staining at indicated concentrations. (B) Concentration-dependent effect of taraxerol on cell apoptosis. $(n=3),{ }^{*} p<0.01$.
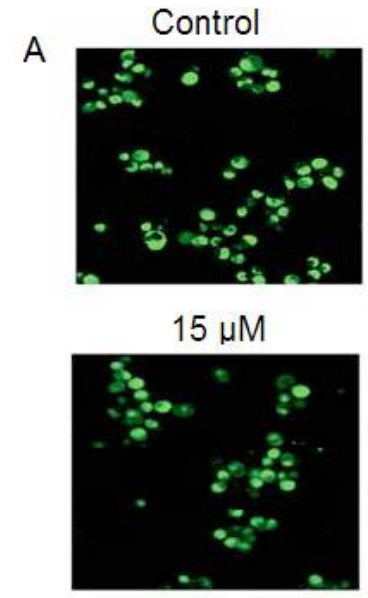

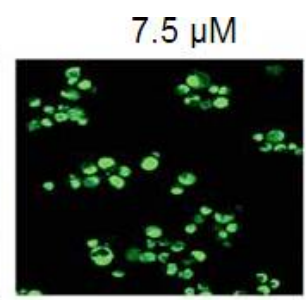

$30 \mu \mathrm{M}$

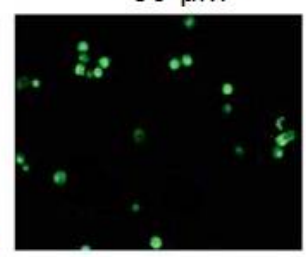

B

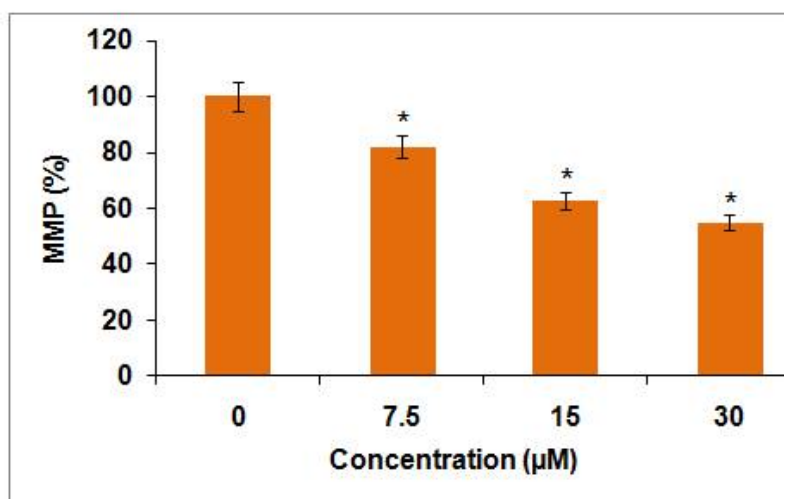

Figure 4: Effect of taraxerol on mitochondrial membrane potential. (A) Rhodamine-123 staining of human middle ear epithelial cholesteatoma cells at indicated doses. (B) Concentration-dependent taraxerol on mitochondrial membrane potential. $(\mathrm{n}=3),{ }^{*} p<0.01$. 

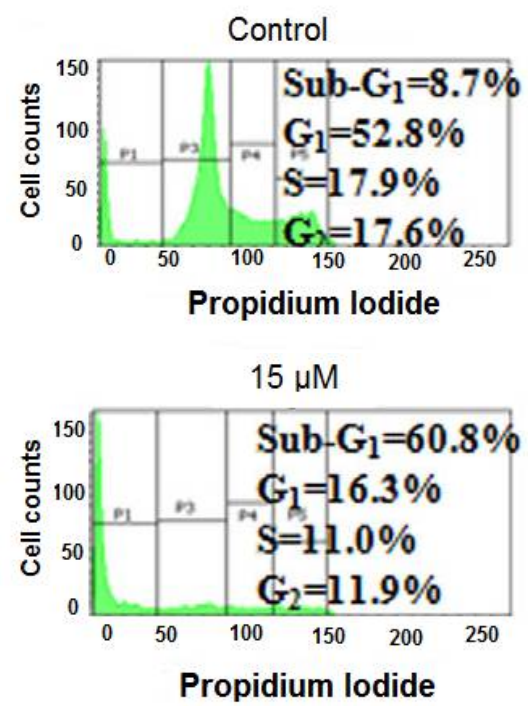
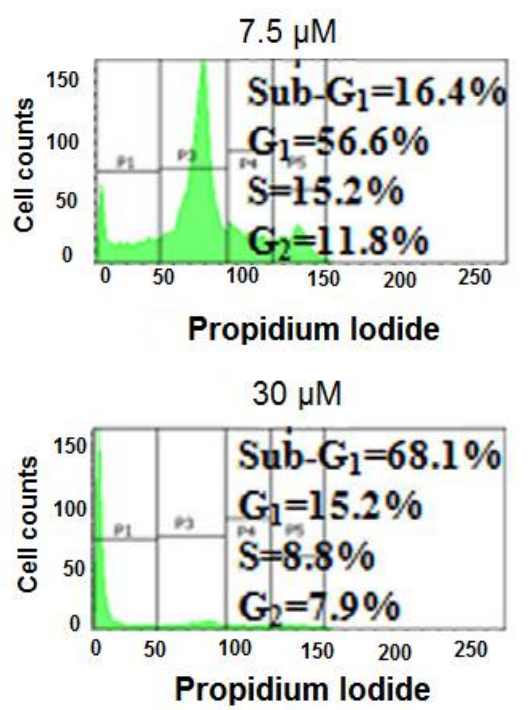

Figure 5: Effect of taraxerol on cell cycle phase distribution of human middle ear epithelial cholesteatoma cells at the indicated doses. ( $\left.{ }^{*} p<0.01\right)$.

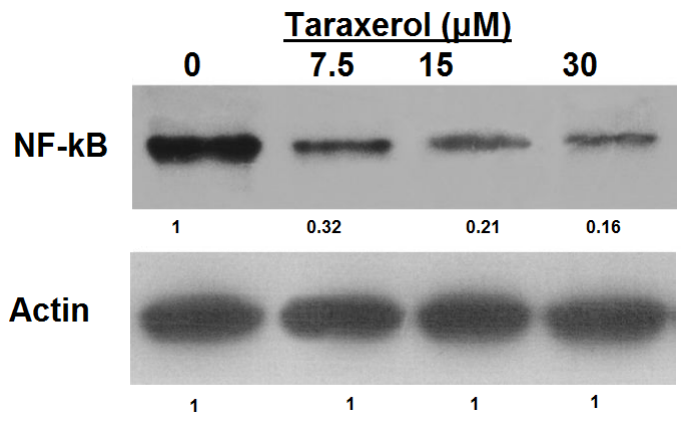

Figure 6: Effect of taraxerol on the expression of NfkBin human middle ear epithelial cholesteatoma cells at indicated doses $(n=3)$

\section{DISCUSSION}

Middle ear cholesteatoma is caused by proliferation of epithelial tissues, resulting in serious complications. The aetiology of this pathological condition is not well understood $[1,2]$. Moreover, the current treatments are not satisfactory, and are associated with side-effects [3]. Therefore, it is believed that development of new effective treatment options with minimal side-effects may prove beneficial. Natural products have a long history of being used for the treatment of several diseases and disorders [5]. In different systems of medicine including Chinese system of traditional medicine, Ayurveda and Unani medicine, different plant extracts and decoctions are used to treat a diversity of pathological conditions [6]. In most of the cases, treatments based on these traditional remedies have produced very effective outcomes. Indeed, researchers across the globe have used the knowledge from these traditional systems to isolate compounds that are effective in the treatment of several diseases and disorders [5].

Several compounds that are currently used as drugs were isolated from plants. For instance, podophyllotoxin, artemisinin and several other drugs were isolated from plants, and have shown tremendous therapeutic potential $[5,6]$. As part of the search program for natural bioactive compounds that can inhibit the proliferation of middle ear epithelial cholesteatoma cells, the present study was focussed on the antiproliferative effects of taraxerol.

Preliminarily, the anti-proliferative effect of taraxerol on ear epithelial cholesteatoma cells was evaluated by CCK8 and clonogenic assays. The results clearly showed that taraxerol suppressed the proliferation of these cells dosedependently. Furthermore, results from colony formation assay complimented the results of CCK8 assay, and showed that taraxerol inhibited the colony-forming potential of the epithelial cholesteatoma cells. These results are in agreement with the results reported in a previous study wherein taraxerol was shown to inhibit the proliferation of several cancerous cells $[14,15]$.

It has been reported that anti-proliferative agents inhibit the growth of the cells through apoptosis and cell cycle arrest, which are two important mechanisms that have been found effective in the elimination of the malignant and harmful cells $[16,17]$. Therefore, in the present study, investigation was carried out to see if taraxerol could induce apoptosis in epithelial cholesteatoma cells. Interestingly, it was shown that taraxerol triggered apoptosis in 
cholesteatoma epithelial cells in a dose dependent manner.

To investigate if this apoptosis follows mitochondrial pathway, mitochondrial membrane potential levels were also evaluated. The results showed that taraxerol reduced mitochondrial membrane potential dose-dependently. Previous investigations have also indicated that taraxerol prompts apoptosis in human gastric epithelial cells [18]. In the present study, it was observed that treatment of the epithelial cholesteatoma cells with taraxerol caused considerable accumulation of the cells in sub-G1 phase of the cell cycle, resulting in sub-G1 cell cycle arrest. Several anti-proliferative agents have been reported to induce cell cycle arrest in human cells $[16,19]$.

In addition, it has been observed that Nf-kB signalling pathway is upregulated in cholesteatoma epithelial cells and could prove to be an important therapeutic target [20]. Therefore the effect of taraxerol on the expression of Nf-kB was investigated by western blot analysis, and the results showed that taraxerol suppressed the expression of $\mathrm{Nf}-\mathrm{kB}$ in a concentrationdependent manner.

\section{CONCLUSION}

The results obtained in this study indicate that taraxerol triggers apoptosis and cell cycle arrest in middle ear epithelial cholesteatoma by inhibiting the expression of Nf-kB. Hence, taraxerol may be beneficial in the management of amiddle ear cholesteatoma.

\section{DECLARATIONS}

\section{Acknowledgement}

This study was supported by Science and Technology Project For Social Development of Quanzhou (no. 2013Z60).

\section{Conflict of interest}

There is no conflict of interest with regard to this work.

\section{Contribution of authors}

We declare that this work was done by the authors named in this article and all liabilities pertaining to claims relating to the content of this article will be borne by the authors. This paper was written and the whole study was designed by Jun Liao. Fengfang $\mathrm{Wu}$, Wen Lin, Zhiwei
Huang offer assistance for performing experiments under the supervision of Jun Liao.

\section{REFERENCES}

1. Bujia J, Schilling $V$, Holly $A$, Stammberger $M$, Kastenbauer E. Hyperproliferation-associated keratin expression in human middle ear cholesteatoma. Actaoto-laryngologica 1993; 113(3): 364-368.

2. Kojima $H$, Tanaka $Y$, Tanaka $T$, Miyazaki $H$, Shiwa $M$, Kamide $Y$, Moriyama $H$. Cell proliferation and apoptosis in human middle ear cholesteatoma. Archiv Otolaryngol Head Neck Surg 1998; 124(3): 261-264.

3. Bujia J, Kim C, Ostos P, Hültner L. Role of interleukin 6 in epithelial hyperproliferation and bone resorption in middle ear cholesteatomas. Euro Archive Oto-rhinolaryngol 1996; 253(3): 152-157.

4. Van Blitterswijk CA, Hesseling SC, Grote JJ, Koerten HK, De Groot K. The biocompatibility of hydroxyapatite ceramic: a study of retrieved human middle ear implants. J Biomed Mat Res Part A 1990; 24(4): 433453.

5. Newman DJ, Cragg GM, Snader KM. Natural products as sources of new drugs over the period 1981-2002. J Nat Prod 2003; 66(7): 1022-1037.

6. Williams TI. Drugs from plants. Sigma Books; London; 1947.

7. Swain SS, Rout KK, Chand PK. Production of triterpenoid anti-cancer compound taraxerol in Agrobacteriumtransformed root cultures of butterfly pea (Clitoriaternatea L.). Appl Biochem Biotechnol 2012; 186(1): 1-7.

8. Kumar V, Mukherjee K, Kumar S, Mal M, Mukherjee PK. Validation of HPTLC method for the analysis of taraxerol in Clitoriaternatea. Phytochem Anal 2008; 19(3): 244250.

9. Singh B, Sahu PM, Sharma MK. Anti-inflammatory and antimicrobial activities of triterpenoids from StrobilanthescallosusNees. Phytomed 2002; 9(4): 355359.

10. Sun C, Liu Z, Li S, Yang $C$, Xue R, Xi Y, Wang L, Wang $S$, He Q, Huang J, Xie S. Down-regulation of $c-M e t$ and Bcl2 by microRNA-206, activates apoptosis, and inhibits tumor cell proliferation, migration and colony formation. Oncotarget. 2015; 6(28): 25533.

11. Wang $Y$, Shi $L Y$, Qi WH, Yang J, Qi Y. Anticancer activity of sugiol against ovarian cancer cell line SKOV3 involves mitochondrial apoptosis, cell cycle arrest and blocking of the RAF/MEK/ERK signalling pathway. Archiv Med Sci 2017; 13(1): 1-7.

12. Jiang $K$, Wang $W$, Jin $X$, Wang $Z$, Ji $Z$, Meng G. Silibinin, a natural flavonoid, induces autophagy via ROSdependent mitochondrial dysfunction and loss of ATP involving BNIP3 in human MCF7 breast cancer cells. Oncol Rep 2015; 33(6): 2711-2718.

13. Zhu H, Lv G, Qu Q, Xu J, Zhang L, Zhu Y. Thunder god vine extract exerts antiproliferative effects on growth of human colon cancer cells and inhibits colon cancer

Trop J Pharm Res, June 2018; 17(6): 1016 
growth in xenograft mice models. South Afr J Bot 2018; 31: 115: 18-23.

14. Touitou Y, Portaluppi F, Smolensky MH, Rensing L. Ethical principles and standards for the conduct of human and animal biological rhythm research. Chronobiollnt 2004; 21(1): 161-170.

15. Hong JF, Song YF, Liu Z, Zheng ZC, Chen HJ, Wang SS. Anticancer activity of taraxerol acetate in human glioblastoma cells and a mouse xenograft model via induction of autophagy and apoptotic cell death, cell cycle arrest and inhibition of cell migration. Molecular medicine reports 2016; 13(6): 4541-4548.

16. Pietenpol JA, Stewart ZA. Cell cycle checkpoint signalling: Cell cycle arrest versus apoptosis. Toxicol 2002; 181: 475-481.

17. Zheng WL, Wang BJ, Wang L, Shan YP, Zou $H$, Song $R L$, Wang $T$, Gu JH, Yuan Y, Liu XZ, Zhu GQ. ROS-
Mediated Cell Cycle Arrest and Apoptosis Induced by Zearalenone in Mouse Sertoli Cells via ER Stress and the ATP/AMPK Pathway. Toxins 2018; 10(1): 24.

18. Tan B, Shi HL, Ji G, Xie JQ. Effects of taraxerol and taraxerol acetate on cell cycle and apoptosis of human gastric epithelial cell line AGS. Zhong xi yijie he xuebao $=J$ Chinese Integr Med 2011; 9(6): 638-642.

19. Fang Z, Xu X, Zhou Z, Xu Z, Liu Z. Effect of metformin on apoptosis, cell cycle arrest migration and invasion of A498 cells. Molecular medicine reports. 2014; 9(6): 2251-2256.

20. Yan SD, Huang CC. Tumor necrosis factor alpha in middle ear cholesteatoma and its effect on keratinocytes in vitro. Ann Otol Rhinol Laryngol 1991; 100(2): 157161. 